\title{
Pathophysiology of bronchial smooth muscle remodelling in asthma
}

\author{
I. Bara*\#, A. Ozier*,\#, J-M. Tunon de Lara*,\#, , R. Marthan*,\#, and P. Berger*,\#,
}

ABSTRACT: Whereas the role of bronchial smooth muscle remains controversial in healthy subjects its role is well established in asthmatics. Bronchial smooth muscle contraction induces airway narrowing. The smooth muscle also contributes to bronchial inflammation by secreting a range of inflammatory mediators, recruiting and activating inflammatory cells, such as mast cells or T-lymphocytes. In addition, bronchial smooth muscle mass is significantly increased in asthma. Such an increase has been related to a deposition of extracellular matrix proteins, and an increase in both cell size and number. However, the mechanisms of this smooth muscle remodelling are complex and not completely understood. The article will review recent data regarding the pathophysiology of bronchial smooth muscle remodelling in asthma.

\section{KEYWORDS: Asthma, bronchi, proliferation, remodelling, smooth muscle}

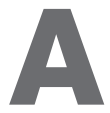
sthma is a chronic inflammatory disease, characterised by the association of bronchial hyperresponsiveness, inflammation and remodelling [1-3]. Current medications are effective in treating acute airway narrowing and decreasing inflammation but are relatively less effective in preventing chronic structural changes [4]. Bronchial remodelling is described as an increased thickening of the bronchial wall due to various structural alterations including: abnormal epithelium; sub-epithelial membrane thickening; alteration in extracellular matrix (ECM) deposition; neoangiogenesis; mucus gland hypertrophy; and an increased bronchial smooth muscle (BSM) mass (fig. 1). The latter appears to be the most important feature of bronchial remodelling since increased BSM mass is associated with a decrease in lung function in severe asthma [5, 6]. However, major anti-asthmatic treatments, such as corticosteroids, remain totally ineffective in decreasing BSM mass [4]. As a result, innovative treatments such as bronchial thermoplasty [7, 8] aim to target BSM.

The physiological role of BSM remains controversial. BSM is known to contribute to the normal branching of the respiratory tree during lung embryogenesis $[9,10]$. In healthy subjects, BSM may play a role in co-ordinating the distribution of ventilation within the airways [11, 12], in mucus propulsion [13] or in helping exhalation [14]. However, these potential roles have not been experimentally validated. MitzNER [15] suggested that BSM is vestigial and has no physiological function, stating that BSM is "the appendix of the lung". Paradoxically, the pathophysiological role of BSM in asthma is well established. BSM is the main effector of bronchial contraction in response to various stimuli, including inflammatory mediators. Moreover, BSM has also been considered as an inflammatory cell per se [16]. It can contribute to an autoactivation loop involving mast cells and implicating the production of cytokines [17]. Upon stimulation, BSM cells produce a wide range of cytokines and chemokines including CXCL10 (IP10) and $C X_{3} C L 1$ (Fraktalkine), which participate in this auto-activation loop [18, 19]. As a result, mast cells are attracted by BSM and preferentially infiltrate the BSM layer of both fatal and nonfatal asthmatics [20, 21]. As part of this auto-activation loop, mast cells can adhere to BSM cells [2, 22, 23], promoting both survival and proliferation of mast cells [24]. Mast cell activation and degranulation can be allergen dependent or independent [25-28], and can be responsible for an important extracellular deposition of inflammatory products that may facilitate the increase in BSM mass, as well as bronchial hyperresponsiveness $[16,29,30]$. T-lymphocytes may also participate in BSM remodelling. LAZAAR et al. [31] demonstrated that the adhesion of T-lymphocytes to BSM cells induced BSM cell DNA synthesis. More recently, this increased BSM proliferation was related to a direct contact between activated
AFFILIATIONS

*Université de Bordeaux, UB2,

Laboratoire de Physiologie Cellulaire Respiratoire,

\#INSERM, U885, and

"CHU de Bordeaux, Bordeaux, France.

CORRESPONDENCE

P. Berger

Service d'Exploration Fonctionnelle

Respiratoire, Hôpital du Haut-

Lévèque

CHU de Bordeaux

Avenue de Magellan

F 33604 Pessac

France

E-mail: patrick.berger@

chu-bordeaux.fr

Received:

Feb 042010

Accepted after revision:

March 132010 

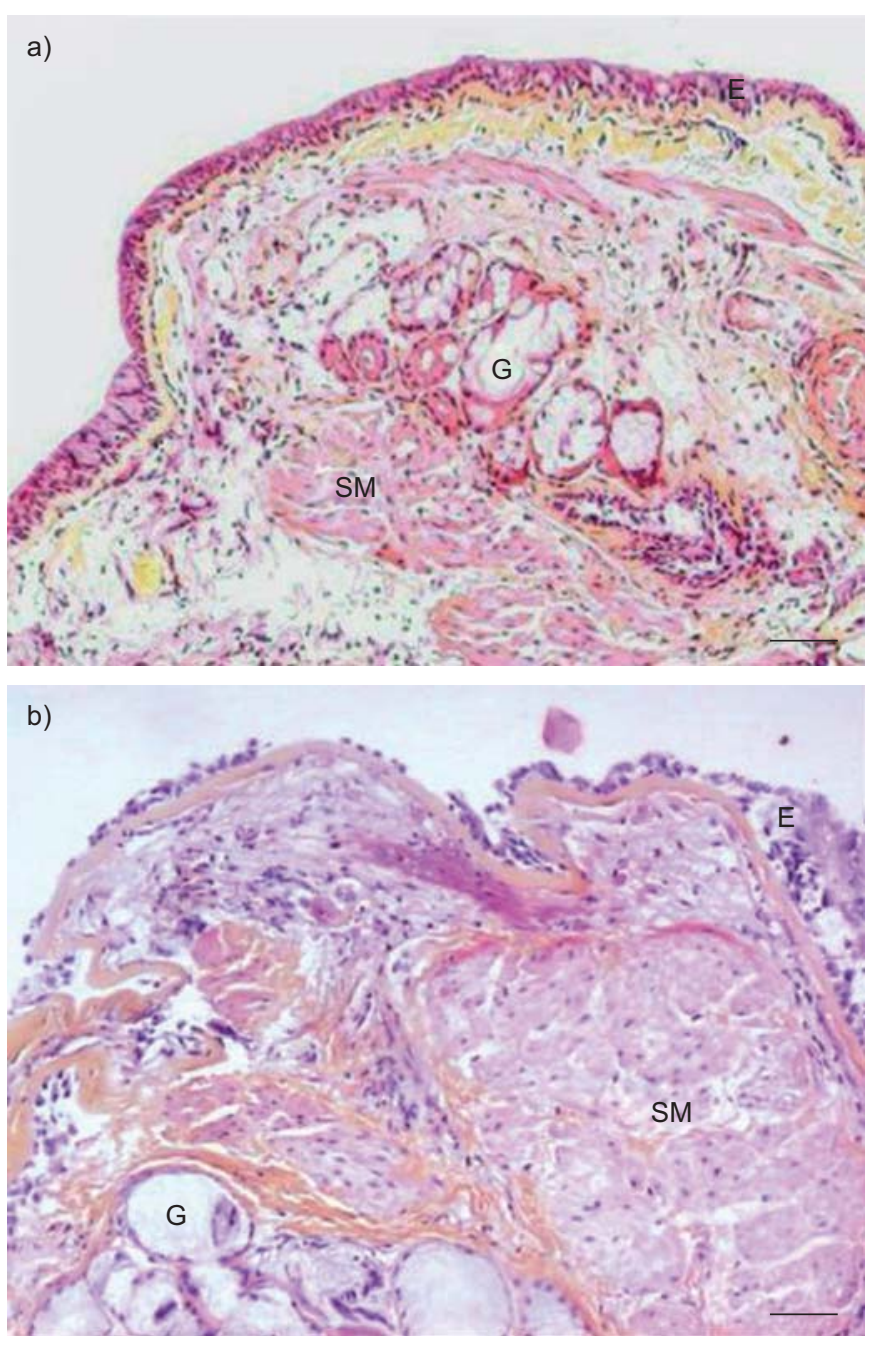

FIGURE 1. Representative optic microscopic images from bronchial sections stained with Haematoxylin, Eosin and safranin stain were obtained from a) a control subject or b) an asthmatic subject. E: epithelium; G: mucous gland; SM: smooth muscles. Scale bars $=50 \mu \mathrm{m}$.

$\mathrm{CD}^{+} \mathrm{T}$-cells and BSM cells using cells from a rat experimental model of asthma [32].

Bronchial chronic asthmatic inflammation causes tissue injuries leading to repetitive repair processes. Remodelling was initially thought to be the consequence of an incomplete repair process in asthma [33]. However, the early onset of this process [34, 35] sometimes before eosinophilic inflammation [36] suggests that bronchial inflammation and remodelling may occur simultaneously in asthma. BSM remodelling is characterised by an increased deposition of ECM proteins in and around the BSM bundles, an increased BSM cell size or hypertrophy, and an increased BSM cell number or hyperplasia (fig. 2). The aim of our article is to review recent data regarding these specific aspects of the pathophysiology of BSM remodelling in asthma.

\section{ALTERED ECM WITHIN THE SMOOTH MUSCLE LAYER}

There is a growing body of evidence indicating that the BSM ECM is altered in asthma [29,37-39]. Indeed, ECM is increased around each individual BSM cell within the muscle bundles [37], by large bland amount of protein deposits [29]. Such an increased ECM contains a higher amount of collagen [38] and both fibronectin and elastic fibres, although the latter has only been found within the BSM from fatal asthma [39]. Several of these characteristics have been described in both large and small airways [39]. Cultured human nonasthmatic BSM cells produce a wide range of matrix proteins, including fibronectin, perlecan, elastin, laminin, thrombospondin, chondroitin sulfate, collagen I, III, IV and V, versican and decorin [40]. Interestingly, asthmatic BSM cells produce an altered profile of ECM proteins in vitro, characterised by more collagen I and perlecan, but less laminin- $\alpha 1$, collagen IV [41] and hyaluronan [42]. Such an altered ECM production by BSM cells could contribute to the altered ECM composition of the whole asthmatic bronchial wall. Indeed, asthmatic bronchial ECM is characterised by an increased amount of collagen I, collagen III and fibronectin [43-45] and a decreased amount of collagen IV [46]. However, bronchial ECM also presents higher amount of hyaluronan, versican, and laminin [43, 47], which may be produced by cells different from BSM, such as epithelial cells and/or an imbalance between matrix production and degradation.

The increased ECM deposition may also be due to decreased matrix metalloproteinases (MMP) or increased tissue inhibitors of matrix metalloproteinases (TIMP). However, in biopsies from fatal asthmatics, both MMP-9 and MMP-12 were increased within the BSM, whereas no change was observed in the expression of MMP-1, MMP-2, TIMP-1 and TIMP-2 [39]. However, these findings seem to be restricted to fatal asthma cases since no significant difference has been demonstrated in the BSM from nonfatal asthmatics [39]. MMP-9 degrades collagen IV, a major component of the airway sub-epithelial basement membrane [48], and MMP-12 is implicated in elastin, collagen IV, fibronectin and laminin digestion $[49,50]$. In vitro, BSM cells from nonasthmatics have been shown to express only a small amount of MMP-9 but also MMP-2, MMP-3, membrane type-1-MMP [51]. Nevertheless, the overall BSM MMP activity remains low due to an excess expression of TIMP-1 and TIMP-2 [51]. Whether MMP-9 production and activity can be upregulated under inflammatory conditions remains unknown. In contrast, MMP-12, which is also expressed by BSM cells, is upregulated by interleukin (IL)- $1 \beta$ or tumour necrosis factor (TNF)- $\alpha$ [52], although such upregulation was not observed in a single report on asthmatic BSM cells in vitro [52]. Nevertheless, an increased expression of both MMP-9 and MMP-3 has been found in the bronchoalveolar lavage (BAL) fluid from asthmatics [53] and could be related to other cell types. For example, eosinophils and neutrophils are also known to be a major source of MMP-9 [48, 54]. In addition, levels of TIMP-1 are higher in untreated asthmatics than in treated subjects [55] although the role of BSM cells in down regulating MMPs by upregulation of TIMPs in asthma remains to be established.

The increased and abnormal asthmatic ECM could interact with growth factors. In particular, transforming growth factor (TGF)- $\beta$ is stored within the ECM as an inactive form combined with the latency-associated peptide [17]. Amongst various enzymes capable of activating TGF- $\beta$, MMP-9 releases the active form of TGF- $\beta$ [56]. TGF- $\beta$ is increased within asthmatic airways $[57,58]$ and more specifically in the BSM 


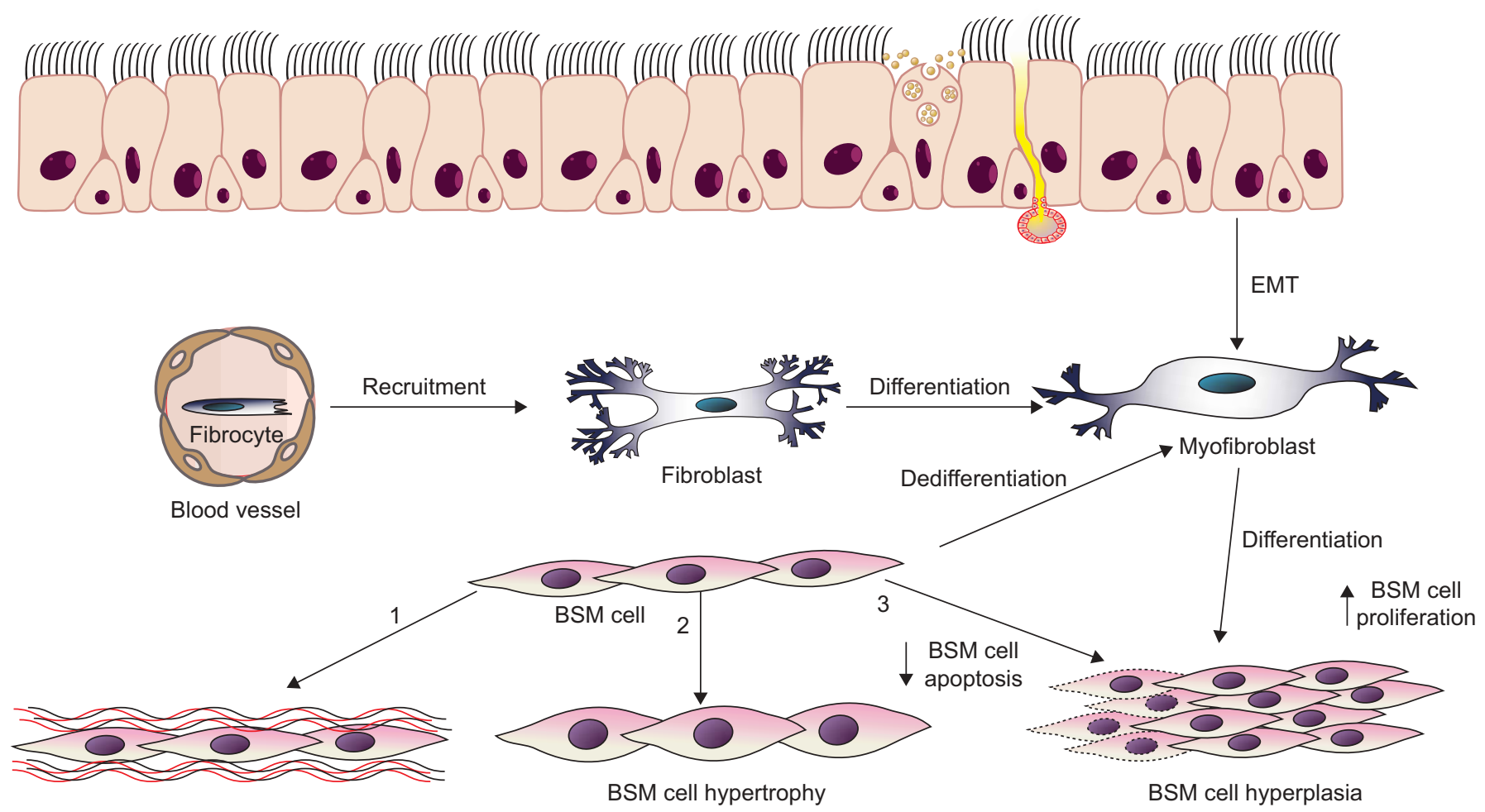

4ECM deposition

FIGURE 2. Mechanisms of asthmatic bronchial smooth muscle (BSM) remodelling. The three main characteristics of BSM remodelling in asthma are presented. BSM cell hyperplasia can be related to an increased cell proliferation, a decreased cell apoptosis or the recruitment of mesenchymal cells. EMT: epithelial mesenchymal transition; ECM: extracelluar matrix.

layer [17]. TGF- $\beta$ induces fibronectin and collagen I deposition from BSM cells through connective tissue growth factor (CTGF)dependent and -independent pathways [59]. Interestingly, CTEF is increased in asthmatic BSM cells [60]. In addition, TGF- $\beta$, which is secreted by BSM cells after mast cell degranulation, induces mast cell chemotaxis and thus participates in an auto-activation loop [17].

Finally, ECM proteins may also modulate BSM phenotype, as well as its functions including contraction, migration and proliferation [61]. On the one hand, fibronectin reduces both the contractility and expression of $\alpha$-actin, calponin and myosin heavy chain in bovine BSM strips [62]. On the other hand, laminin increases the contractility of bovine BSM strips [62], and induces the maturation of human BSM cells into a contractile phenotype [63]. Conversely, fibronectin enhances BSM cell proliferation in response to platelet-derived growth factor (PDGF) or thrombin, whereas laminin decreases BSM cell proliferation [64]. Thus, asthmatic BSM cells that produce an altered ECM influence their own environment, and may, as a consequence, contribute to modulate their own function.

\section{BSM HYPERTROPHY}

Whether BSM hypertrophy is present in asthma remains controversial [29, 65-67]. For some authors, there is evidence that BSM hypertrophy contributes to airway remodelling in asthma. EBINA et al. [67] have examined the airways of fatal asthma, and described two asthmatic subtypes. In particular, the second subtype includes an increased BSM cell size throughout the bronchial tree. More recently, BENAYOUN et al. [65] studied bronchial biopsies and found that patients with asthma had larger BSM cell diameter compared to control subjects. Furthermore, severe asthmatics presented the highest BSM cell size [65]. Interestingly, it has also been shown that asthmatic BSM hypertrophy was associated with an increased expression of myosin light chain kinase (MLCK), whereas that of both $\alpha$ smooth muscle actin (SMA) and myosin was unchanged [65]. In addition, using an ultrastructural approach, BEGUERET et al. [29] also showed an increased BSM cell size in atopic asthmatics. Conversely, using a three-dimensional approach WoODRUFF et al. [66] did not find any evidence of an increase in the BSM cell size in patients with mild-to-moderate asthma. Thus, BSM cell hypertrophy may be related to asthma severity.

The cellular mechanisms of such BSM cell hypertrophy have been addressed using nonasthmatic BSM cells only. In vitro, primary cultured BSM cells obtained from nonasthmatic donors and even from animals or immortalised human BSM cell lines have been examined [68-70]. On the one hand, BSM cell hypertrophy has been reproduced in vitro using serum deprivation [69] or cell stimulation with TGF- $\beta$, endothelin or cardiotrophin-1 [70-72]. On the other hand, a BSM cell line has been obtained using a temperature-sensitive simian virus-40 large T-antigen, which binds to and inactivates p53 [68]. In such a cell line there is an increase in both cell size and amount of $\alpha$-SMA and MLCK in a post-transcriptional manner [68]. BSM hypertrophy involved complex transduction pathways (fig. 3), recently reviewed by BENTLEY and Hershenson [73]. As 
a summary, two distinct pathways could activate BSM cell hypertrophy. The first pathway involves the mammalian target of rapamycin (i.e. mTOR). mTOR induces the phosphorylation of $4 \mathrm{E}-$ binding protein (4E-BP), which releases the transcription factor eIF4E leading to BSM cell hypertrophy [74]. In addition, mTOR also phosphorylates p70S6-kinase, which activates S6 kinase [75]. Such a pathway is necessary and sufficient for BSM cell hypertrophy. In addition, when TGF- $\beta$ is used to induce BSM cell hypertrophy in vitro the phosphorylation of $4 \mathrm{E}-\mathrm{BP}$ appears to be more phosphatidylinositol 3-kinase (PI3)-kinasedependent than mTOR-dependent, whereas that of p70S6kinase only requires mTOR activation [70]. The possible upstream inhibition of mTOR by tuberous sclerosis complex-2 has not been demonstrated in BSM cells but has been confirmed in other cell types, including HEK293 [76]. The second pathway involves the inhibition of glycogen synthase kinase (GSK)-3 $\beta$, for instance by Akt. GSK-3 $\beta$ usually inhibits the translation initiation by eIF2B in many cell types [77, 78]. Inhibition of GSK3- $\beta$ induces BSM cell hypertrophy through an eIF2B-dependent manner [79]. Furthermore, in a recent in vivo study using ovalbumin-sensitised mice, BENTLEY et al. [80] have demonstrated that GSK3- $\beta$ is phosphorylated and thus inactivated within the hypertrophic BSM cells. Whether these transduction pathways are actually implicated in human asthmatic BSM cell hypertrophy remains to be established and further studies are needed to explore the involvement of such pathways in asthmatic BSM cells.

\section{BSM HYPERPLASIA}

In contrast to hypertrophy, hyperplasia, i.e. an increased number of BSM cells within the asthmatic airways, is now

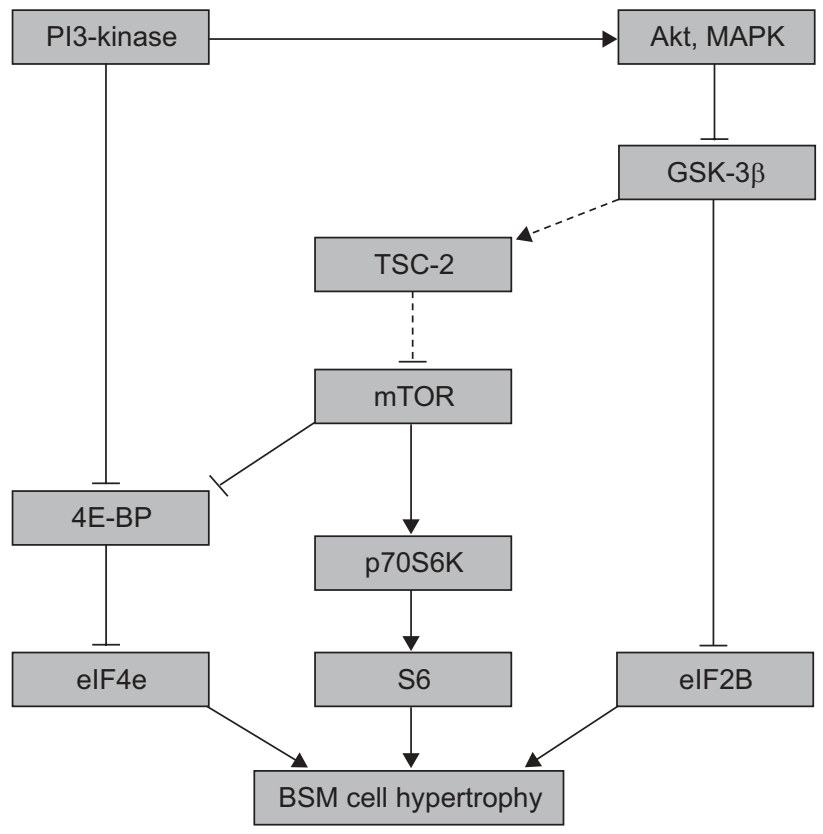

FIGURE 3. Mechanisms of bronchial smooth muscle (BSM) cell hypertrophy Signal transduction mechanisms of BSM cell hypertrophy involve both mammalian target of rapamycin (mTOR) and glycogen synthase kinase (GSK)-3ß. Upstream and down-stream transduction cascades are presented. $\rightarrow$ : activation -1 : inhibition; ......: indicates that the transduction pathway has not yet been demonstrated in BSM cells. well established $[66,67,81,82]$. Thus, BSM hyperplasia is an important feature leading to the increased BSM mass. Nevertheless, the mechanism responsible for this increased BSM cell number is still under debate. An increased proliferation and/or a decreased apoptosis of BSM cells have been initially suggested. More recently, migration of mesenchymal cells to the BSM bundles followed by differentiation toward BSM cells has also been suggested (fig. 2).

\section{BSM cell proliferation}

BSM cell hyperplasia has been associated with an increased proliferation rate in vitro [83]. Indeed, a wide range of mitogens increases the proliferation of nonasthmatic BSM cells (table 1). These factors can be separated into several categories including growth factors/cytokines activating receptor tyrosine kinase (RTK), inflammatory mediators activating G protein coupled receptors (GPCR) and enzymes. In addition, reactive oxygen species (ROS) [98] and mechanical stress [99] have also been implicated (table 1). The main intracellular pathways of BSM cell proliferation have been summarised in the recent review of TLIBA et al. [100]. Briefly, the majority of in vitro studies support an important role of both PI3K and extracellular signalregulated kinase (ERK) activation for both RTK and GPCR. Indeed, activation of RTK or GPCR induces p21ras activation, which subsequently activates PI3K and/or ERK. On the one hand, PI3K activates both PDK-1/p70S6K and Rac1/reduced nicotinamide adenine dinucleotide phosphate (NADPH) which increase the expression of cyclin D1 [100, 101]. It should be noticed that the GTPase protein Rac1 constitutes part of the NADPH oxidase complex that generates superoxide ion and hydrogen peroxide [102]. In this connection, serum treatment of human BSM cells increases intracellular endogenous ROS [103]. On the other hand, ERK phosphorylates and directly increases the expression of cyclin D1 [104] in the absence of endogenous ROS implication [105]. Regarding transduction pathways involved by exogenous ROS, ERK is activated upon PKC and Raf1 stimulation [106, 107]. Furthermore, KRYMSKAYA et al. [108] have demonstrated that GPCR activation by inflammatory or contractile agonists along with RTK activation enhances human BSM growth. WALKER et al. [109] have shown that even if the PI3K pathway is sufficient to stimulate proliferation, ERK parallel signalling is required to induce a full mitogenic response. Among the various enzymes able to induce BSM cell proliferation (table 1) great attention has been paid to tryptase. Indeed, upon degranulation, mast cellreleased tryptase stimulates BSM cell proliferation and DNA synthesis $[95,110]$. However, the mechanisms of such an effect remain controversial. BROWN et al. [110] did not find any effect of tryptase inactivation, suggesting a nonenzymatic effect, whereas heat inactivation or the enzyme inhibitor leupeptin abolished tryptase-induced BSM cell proliferation [95]. Thus, our data suggest an enzymatic effect of tryptase, but the involvement of protease-activated receptor (PAR)-2, a potential target of tryptase, has only been demonstrated in tryptaseinduced calcium increase [111, 112]. Therefore, the role of PAR-2 in tryptase-induced BSM cell proliferation requires further investigation. Regarding the effect of mechanical stress, cyclic stretch alters BSM cell proliferation [99]. Indeed, in canine BSM cells subjected to a stretch-relaxation regimen, $\left[{ }^{3} \mathrm{H}\right]$-thymidine incorporation is increased [99]. More recently, mechanical strain has been shown to induce human BSM cell 


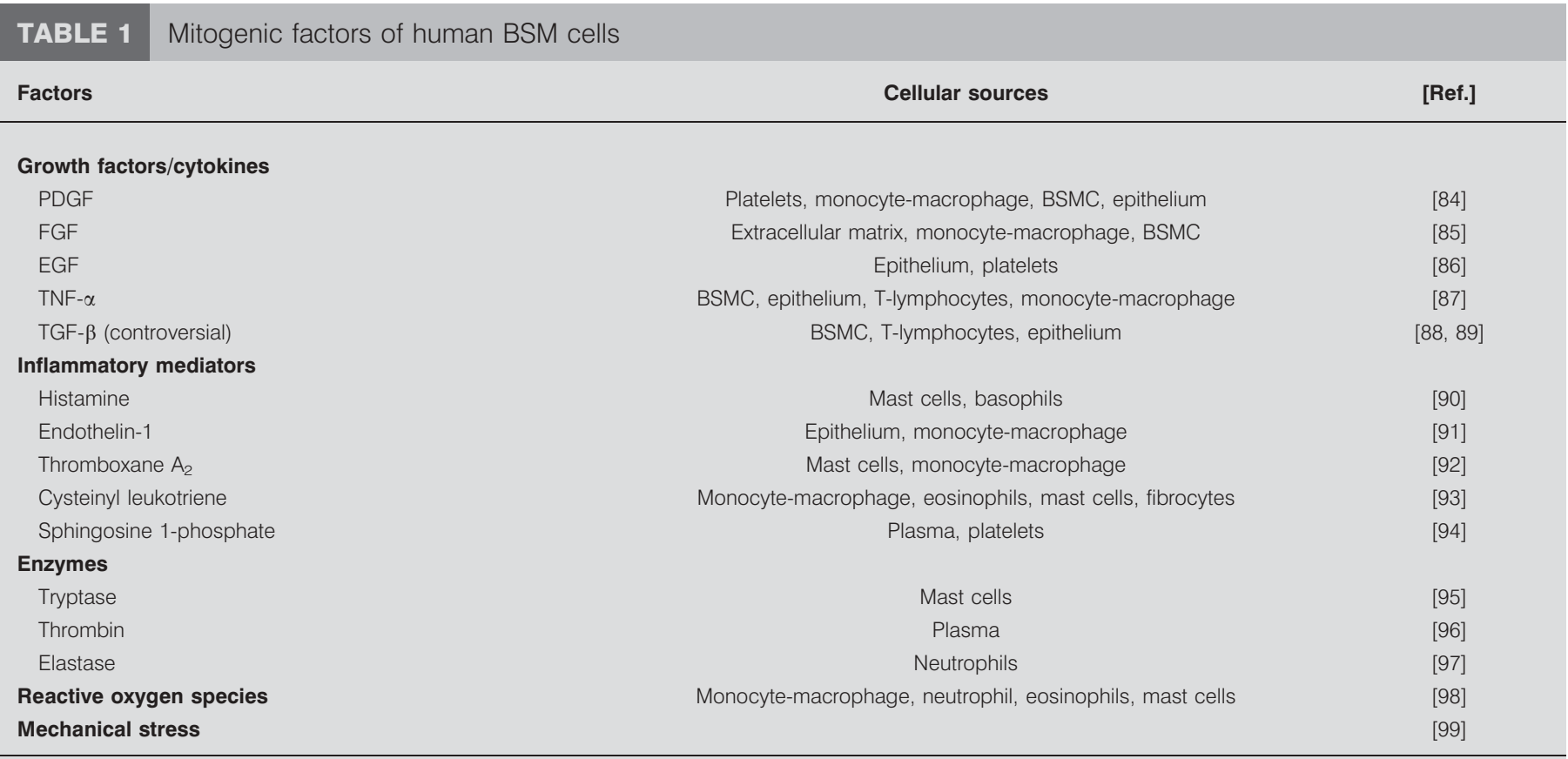

PDGF: platelet-derived growth factor; FGF: fibroblast growth factor; EGF: epidermal growth factor; TNF: tumour necrosis factor; TGF: transforming growth factor; BSMC: bronchial smooth muscle cells.

proliferation in a MMP-dependent manner [113]. Mechanical stress was accompanied by an increased expression and activation of several MMPs including MMP-1, MMP-2, MMP-3 and MT1-MMP, suggesting that such a proliferation of human BSM cells requires the release and activation of MMPs [113]. Indeed, mechanical stress is influenced by the abundance of ECM. HIRST et al. [64] have shown that fibronectin and collagen I enhance BSM cell proliferation in response to PDGF or thrombin, whereas laminin causes a reduction in BSM cell proliferation. All these promoting factors are increased within the asthmatic airways and can target BSM cells. Indeed, BAL fluid obtained from asthmatic subjects induces the proliferation of human BSM cells [114].

In addition to this excess in mitogenic mediators, there is a growing body of evidence to show that asthmatic BSM cells have intrinsic properties leading to excessive proliferation. JOHNSON et al. [115] firstly reported an increased proliferation rate of cultured asthmatic BSM cells compared to that of nonasthmatics. Such findings have been confirmed in various cohorts of patients [4,116-118] including in severe asthmatics [81]. Whereas, the proliferation of nonasthmatic BSM cells is decreased by steroids [119], that of asthmatic BSM cells is insensitive to steroids [4]. Indeed, glucocorticoids downregulate the proliferation of nonasthmatic BSM cells by decreasing the expression of cyclin D1 and the phosphorylation of retinoblastoma protein, but have no effect on ERK signalling [120]. No significant difference in glucocorticoid receptor expression was found in BSM between mild asthmatic and nonasthmatic patients [121]. Several studies have pointed out the role of the transcription factor CCAAT-enhancer binding proteins (c/EBP). The $\mathrm{c} / \mathrm{EBP}$ form a family of transcription factors involved in the regulation of cellular differentiation, cell-cycle regulation and cytokine gene expression [122]. Lack of $\mathrm{c} / \mathrm{EBP} \alpha$ has been specifically demonstrated within the asthmatic BSM cells and may explain the absence of an anti-proliferative action of glucocorticoids [4]. Indeed, the glucocorticoid receptor usually forms a complex with $\mathrm{c} / \mathrm{EBP} \alpha$ in nonasthmatic BSM cells, which then binds to the CCAAT DNA consensus sequence in the p21 promoter [123]. This complex is absent in asthmatic BSM cells after glucocorticoid treatment [4]. In addition, this transcription factor may be important in other processes, including contractility of BSM cells, since $c / E B P \alpha$ is a possible negative regulator of MLCK expression [124].

Although the existence of dual signalling pathways regulating proliferation of nonasthmatic BSM cells is well established, a recent study has demonstrated that $\mathrm{PI} 3 \mathrm{~K}$ is the predominant pathway leading to proliferation of BSM cells from asthmatic patients [116]. Furthermore, we have demonstrated that the mechanism leading to the increased proliferation rate observed in asthmatic BSM cells was mitochondrial dependent, since mitochondria-deficient BSM cells from severe asthmatics are unable to proliferate [81]. Indeed, asthmatic BSM express a higher number of active mitochondria and a clear aspect of intense mitochondrial biogenesis, both in vivo and in vitro. This enhanced mitochondrial biogenesis is induced by the upregulation of peroxisome proliferator-activated receptor- $\gamma$ co-activator (PGC)-1 $\alpha$, nuclear respiratory factor-1 and mitochondrial transcription factor A [81]. This feature appears to be responsible for asthmatic BSM cell proliferation, since depleting mitochondria from BSM cells abolishes the proliferation. Interestingly, the upstream mechanism is related to altered calcium homeostasis in severe asthmatic BSM cells leading to increased phosphorylation of CaMK-IV, which induces the 
transcription of PGC-1 $\alpha$ [81]. Such an altered calcium homeostasis has also been observed very recently in nonsevere asthmatics [118], although the mechanism appeared to be different according to asthma severity. In severe asthmatic BSM cells, the proliferation has been related to an abnormal calcium influx [81], whereas in nonsevere asthmatic BSM cells, a diminished expression of SERCA2 has been demonstrated [118] In addition, knocking down SERCA2 in healthy BSM cells reproduced this enhanced proliferation rate [118]. Thus, transduction pathways leading to the proliferation of asthmatic BSM cells seems to depend on the severity of the disease. However, further studies need to address whether or not the increased mitochondrial biogenesis and altered $\mathrm{Ca}^{2+}$ homeostasis can be related to exogenous factors such as those secreted by inflammatory cells.

Finally, to date no feature of BSM cell mitoses has been observed in human asthmatic tissues, using either Ki67 or proliferating cell nuclear antigen (PCNA), two markers of nuclear antigen expressed by proliferating cells $[29,65]$. Nevertheless, the lack of Ki67 or PCNA staining within the asthmatic BSM does not formally exclude the absence of cell proliferation. Indeed, increased proliferation may have occurred before biopsy, as already suggested [125]. In addition, these markers may be poorly sensitive for BSM cell proliferation. In contrast, BSM hyperplasia may be related to a decreased apoptosis or the migration of BSM cells and/or mesenchymal cells.

\section{BSM cell apoptosis}

To date, little is known about the cellular mechanisms of apoptosis in asthmatic BSM cells. Besides, most of the current knowledge has only been established using nonasthmatic BSM cells. As for hypertrophy, either primary cultured BSM cells obtained from patients undergoing lung resection surgery [71, 126-128] or BSM cell line have been investigated [72]. In these healthy BSM cells, Fas receptor is expressed both in vivo and in vitro and its cross linking induces cell apoptosis [126], suggesting that it may participate in normal BSM cell turn over. Moreover, neutrophil elastase [127] and the ECM protein decorin [128] also induce BSM cell apoptosis in vitro. Interestingly, a decreased expression of decorin was demonstrated within the bronchial wall of fatal asthmatics [129]. Additionally, both cardiothrophin-1 [72] and endothelin-1 [71] inhibit BSM cell apoptosis. However, the role of these mediators in asthmatic BSM cell apoptosis requires further investigations.

Few studies have evaluated the susceptibility of BSM cells to apoptosis in asthma and their findings remain controversial. RAMOS-BARBON et al. [32] have demonstrated decreased BSM cell apoptosis in vivo in a rat model of experimental asthma. Conversely, spontaneous apoptosis was unchanged within asthmatic BSM cells in vitro [81, 130]. In addition, the in vivo expression of the TRAIL receptor, a member of the TNF- $\alpha$ receptor family was increased following allergen challenge in asthmatic BSM, suggesting that apoptosis may occur in asthmatic BSM [131]. Therefore, further studies are required to establish whether or not BSM cell apoptosis is actually altered in asthma.

\section{Migration of BSM cells}

Migration of BSM cells is a fundamental process in the development of the airways [132]. Thus, it has been suggested that such a migration may participate in BSM remodelling in asthma [133]. Cellular migration is characterised by cytoskeletal reorganisation starting by actin polymerisation, as was recently reviewed by GERTHOFFER [132]. Briefly, actin filaments push the cell's leading front using focal contacts, enhancing attachment of the cell membrane to the ECM. These focal contacts include integrins, adaptor proteins such as vinculin, regulatory proteins such as Src and proteins controlling myosin activation such as MLCK. Indeed, myosin motors attached to actin filaments generate the force for advancing cells [132].

A wide range of mediators induce BSM cell migration in vitro $[134,135]$. These mediators include growth factors such as PDGF, fibroblast growth factor, TGF- $\beta$, plasma-derived mediators such as plasminogen activators, urokinase, cytokines such as IL1- $\beta[134,135]$ and components from ECM including collagen and fibronectin [136]. In addition, chemokines also induce BSM cell migration. For example, CCR3 ligands such as eotaxin (i.e. CCL11) [137], CXCR1 and CXCR2 ligands such as IL-8 (i.e. CXCL8) [138] and CCR7 ligands such as macrophage inflammatory protein-3 $\beta$ (i.e. CCL19) [139] all induce the migration of nonasthmatic BSM cells in vitro. The epithelium is a significant source of these pro-inflammatory molecules and it has been very recently shown that epithelium-derived chemokines (IL-8 and RANTES) induce human BSM cell migration [140]. In addition, BSM cell production of MMP and its modulation by pro-fibrotic growth factors PDGF and TGF- $\beta$ may contribute to the migratory function of BSM cells [141]. Several studies have shown that the signalling pathways involved in BSM migration include p38, MAPK, Rho-kinase and PI3K $[132,134]$. However, whether or not asthmatic BSM cells migrate more or less than nonasthmatic BSM cells remains unknown.

\section{Migration of myofibroblasts}

A feature of asthmatic bronchial remodelling is the appearance of myofibroblasts within the lamina reticularis, in particular after allergen challenge [142]. Myofibroblasts have been detected between BSM bundles from asthmatics, close to mast cells [29]. Myofibroblasts are thought to originate from resident fibroblasts [143], circulating fibrocytes [144] or from epithelial cells that have undergone transition into mesenchymal cells [145]. Another possibility is that myofibroblasts derive from migrated BSM cells, as previously demonstrated in vascular smooth muscle [146]. Moreover, TGF- $\beta$-stimulated myofibroblasts from asthmatic subjects produce many smooth musclerelated transcripts, suggesting that myofibroblasts may also differentiate into BSM cells [147]. Myofibroblasts could, therefore, be viewed as precursors of BSM cells or the result of a dedifferentiation process of the BSM cells. Furthermore, it may be suggested that BSM cells degrade surrounding ECM and migrate from their original bundles towards the epithelium to eventually form new bundles [113].

In this field of BSM hyperplasia, the role of circulating fibrocytes has recently been examined [148]. These cells derive from the bone marrow and can be quantified in the blood using flow cytometry [144, 149]. Indeed, fibrocytes co-express CD34, vimentin, CD45 and collagen Ia [149]. More recently, WANG et al. [150] demonstrated an increase in blood nonadherent-fibrocytes from asthmatic patients with chronic 
airway obstruction compared to those with normal lung function. This increase was significantly correlated with an annual decline in forced expiratory volume in $1 \mathrm{~s}$, suggesting an important role of fibrocytes in bronchial remodelling. Attraction of fibrocytes to the lung seems to implicate the coupled chemokine/receptors such as CXCL12/CXCR4, CCL19/CCR7 and CCL21/CCR7. To a lesser extent, fibrocyte migration could also involve CCL-5, CCL-7, CCL-8, CCL-11, CCL-13, CCL-15/CCR3, CCL-3, CCL-4, CCL-5/CCR5 and CCL12/CCR2, although the latter has only been implicated in mice [151]. Furthermore, fibrocytes can differentiate into myofibroblasts, as indicated by the expression of $\alpha$-SMA [144, 150]. This phenomenon could be induced by TGF- $\beta$ and is more marked in asthmatics with airway obstruction [150]. As a result, the presence of fibrocytes has been confirmed within the asthmatic airways [144] and more precisely within the BSM bundles [148] or close to the basement membrane [152]. In addition, allergen exposure induces accumulation of fibrocytelike cells within the bronchial mucosa of allergic asthmatic patients [144]. Moreover, NIHLBERG et al. [152] showed that fibroblasts cultured from BAL fluid in patients with mild asthma express fibrocyte proteins, suggesting that fibroblasts derive from circulating fibrocytes. The co-expression of $\alpha$-SMA in fibrocyte-derived cells suggests that circulating progenitor cells differentiate into myofibroblats and then into BSM cells [148]. Finally, BSM cells themselves may promote fibrocytes migration, which is, in part, mediated by the production of PDGF [148].

Another recent concept suggests that myofibroblasts derive from epithelial cell transition to a mesenchymal phenotype [153, 154]. However, this epithelial mesenchymal transition (EMT) remains hypothetical in the genesis of BSM cells and has been mainly studied as a mechanism of fibroblast or myofibroblast generation [153, 154]. For instance, TGF- $\beta$ induces EMT in a smad3-dependent manner using human bronchial epithelial cells [155]. EMT is characterised by an increased expression of mesenchymal markers such as vimentin, collagen 1 and $\alpha$-SMA, with a concomitant loss of epithelial markers such as E-cadherin [155]. Furthermore, TGF- $\beta$-induced EMT is enhanced by IL- $1 \beta$ in human bronchial epithelial cells [156]. Interestingly, airway epithelial cells from asthmatic donors present a similar response to TGF- $\beta$ stimulation, whereas no marker of EMT is spontaneously observed in asthmatic bronchial epithelium [155]. In addition, corticosteroids do not prevent TGF- $\beta$-induced EMT but decrease it [156]. Furthermore, bronchial epithelium modulates BSM cell proliferation through an IL-6 and MMP-9-dependent mechanism [157]. Silencing of MMP-9 abrogates the epithelium-dependent increase in BSM cell proliferation. Finally, epithelial injury increases the release of MMP-9 and the expression of Ki67 levels in human BSM cells [157], suggesting that epithelium and BSM strongly interact in asthma.

\section{BSM-EPITHELIUM INTERACTIONS}

Finally, BSM remodelling must be replaced in the context of other features of asthmatic bronchial remodelling. In particular, bronchial epithelial abnormalities have been extensively studied in asthma [158]. Theses abnormalities include the loss of the most superficial layer of the epithelium and the destruction of ciliated cells. As a result, the physical and functional barrier of the bronchial epithelium is defective in asthma. This may explain the susceptibility of asthmatic airways to respiratory viruses or the impact of environmental factors on asthma exacerbations [159]. For instance, within rhinovirus infections, epithelial cells induce the desensitisation of the $\beta 2$-adrenergic BSM cell receptor [160]. BSM epithelial cell co-culture models have also been developed to evaluate BSMepithelium interactions in vitro [140,157]. Bronchial epithelium in injury modulates BSM cell proliferation through an MMP-9 dependent pathway [157]. However, other epithelium-derived growth factors can also increase BSM cell proliferation (table 1). In addition, upon stimulation with TNF- $\alpha$, bronchial epithelial cells produce higher amount of chemokines, such as IL-8 or RANTES, which subsequently induce BSM migration [140]. However, comprehensive relationships between bronchial epithelium and BSM remain to be investigated, particularly in asthma.

\section{CONCLUSION}

In conclusion, a better understanding of the pathophysiology of asthmatic BSM remodelling is critical to identify new therapeutic targets for BSM remodelling. For example, since mitochondrial biogenesis is implicated in BSM remodelling we have proposed a strategy directed against mitochondria to block BSM cell proliferation [81]. Along the same lines, since endothelin and TGF- $\beta$ have been evoked in the mechanism of BSM cell hypertrophy, it may be interesting to investigate the effect of endothelin- or TGF- $\beta$-receptor antagonists in asthma as already assessed in pulmonary vascular diseases in human [161] or murine models of asthma [162]. More recently, simvastatin has been demonstrated to induce BSM cell apoptosis in vitro [163] but, results from clinical trials remain controversial in asthmatics [164]. Another strategy could focus on the migration of fibrocytes by means of chemokine receptor blockage. Finally, reducing BSM mass may also be achieved by targeting epithelial cells. These targets should now be evaluated by means of clinical trials that may take advantage of newly developed noninvasive tools to quantify BSM remodelling [165-167].

\section{STATEMENT OF INTEREST}

A statement of interest for P. Berger can be found at www. erj.ersjournals.com/site/misc/statements.xhtml

\section{ACKNOWLEDGEMENTS}

We would like to thank M. Chevalier for his support.

\section{REFERENCES}

1 Busse WW, Lemanske RF Jr. Asthma. N Engl J Med 2001; 344 350-362.

2 Girodet PO, Ozier A, Trian T, et al. Mast cell adhesion to bronchial smooth muscle in asthma specifically depends on CD51 and CD44 variant 6. Allergy 2010; 65: 1004-1012.

3 Denis D, Fayon MJ, Berger P, et al. Prolonged moderate hyperoxia induces hyperresponsiveness and airway inflammation in newborn rats. Pediatr Res 2001; 50: 515-519.

4 Roth $\mathrm{M}$, Johnson PR, Borger $\mathrm{P}$, et al. Dysfunctional interaction of $\mathrm{C} / \mathrm{EBP} \alpha$ and the glucocorticoid receptor in asthmatic bronchial smooth-muscle cells. N Engl J Med 2004; 351: 560-574.

5 Pepe C, Foley S, Shannon J, et al. Differences in airway remodeling between subjects with severe and moderate asthma. J Allergy Clin Immunol 2005; 116: 544-549. 
6 Kaminska M, Foley S, Maghni K, et al. Airway remodeling in subjects with severe asthma with or without chronic persistent airflow obstruction. J Allergy Clin Immunol 2009; 124: 45-51.

7 Cox G, Thomson NC, Rubin AS, et al. Asthma control during the year after bronchial thermoplasty. N Engl J Med 2007; 356: 1327-1337.

8 Castro M, Rubin AS, Laviolette M, et al. Effectiveness and safety of bronchial thermoplasty in the treatment of severe asthma: a multicenter, randomized, double-blind, sham-controlled clinical trial. Am J Respir Crit Care Med 2009; 181: 116-124.

9 Sparrow MP, Weichselbaum M, McCray PB. Development of the innervation and airway smooth muscle in human fetal lung. Am J Respir Cell Mol Biol 1999; 20: 550-560.

10 Schittny JC, Miserocchi G, Sparrow MP. Spontaneous peristaltic airway contractions propel lung liquid through the bronchial tree of intact and fetal lung explants. Am J Respir Cell Mol Biol 2000; 23: 11-18.

11 Keith A. The mechanism of respiration in man. In: Hill L, ed. Further Advances in Physiology. New York, Longmans, Green, and Co, 1909; pp. 182-207.

12 Otis AB. A perspective of respiratory mechanics. I Appl Physiol 1983; 54: 1183-1187.

13 Bullowa J, Gottlieb C. Additional experimental studies in bronchial function. Laryngoscope 1992; 32: 284-289.

14 Macklin C. The musculature of the bronchi and lungs. Physiol Rev 1929; 9: 1-60.

15 Mitzner W. Airway smooth muscle: the appendix of the lung. Am J Respir Crit Care Med 2004; 169: 787-790.

16 Berger P, Girodet PO, Tunon De Lara JM. Mast cell myositis: a new feature of allergic asthma? Allergy 2005; 60: 1238-1240.

17 Berger P, Girodet PO, Begueret H, et al. Tryptase-stimulated human airway smooth muscle cells induce cytokine synthesis and mast cell chemotaxis. FASEB J 2003; 17: 2139-2141.

18 Brightling CE, Ammit AJ, Kaur D, et al. The CXCL10/CXCR3 Axis mediates human lung mast cell migration to asthmatic airway smooth muscle. Am J Respir Crit Care Med 2005; 171: 1103-1108.

19 El-Shazly A, Berger P, Girodet PO, et al. Fraktalkine produced by airway smooth muscle cells contributes to mast cell recruitment in asthma. J Immunol 2006; 176: 1860-1868.

20 Brightling CE, Bradding P, Symon FA, et al. Mast-cell infiltration of airway smooth muscle in asthma. $N$ Engl J Med 2002; 346: 1699-1705.

21 Carroll NG, Mutavdzic S, James AL. Distribution and degranulation of airway mast cells in normal and asthmatic subjects. Eur Respir J 2002; 19: 879-885.

22 Thangam EB, Venkatesha RT, Zaidi AK, et al. Airway smooth muscle cells enhance C3a-induced mast cell degranulation following cell-cell contact. FASEB J 2005; 19: 798-800.

23 Yang W, Kaur D, Okayama Y, et al. Human lung mast cells adhere to human airway smooth muscle, in part, via tumor suppressor in lung cancer-1. J Immunol 2006; 176: 1238-1243.

24 Hollins F, Kaur D, Yang W, et al. Human airway smooth muscle promotes human lung mast cell survival, proliferation, and constitutive activation: cooperative roles for CADM1, stem cell factor, and IL-6. J Immunol 2008; 181: 2772-2780.

25 Berger P, Walls AF, Marthan R, et al. Immunoglobulin E-induced passive sensitization of human airways: an immunohistochemical study. Am J Respir Crit Care Med 1998; 157: 610-616.

26 Berger P, N'Guyen C, Buckley M, et al. Passive sensitization of human airways induces mast cell degranulation and release of tryptase. Allergy 2002; 57: 592-599.

27 Berger P, Scotto-Gomez E, Molimard M, et al. Omalizumab decreases nonspecific airway hyperresponsiveness in vitro. Allergy 2007; 62: 154-161.

28 Berger P, Lavallee J, Rouiller R, et al. Assessment of bronchial inflammation using an automated cell recognition system based on colour analysis. Eur Respir J 1999; 14: 1394-1402.
29 Begueret $\mathrm{H}$, Berger $\mathrm{P}$, Vernejoux JM, et al. Inflammation of bronchial smooth muscle in allergic asthma. Thorax 2007; 62: 8-15.

30 Berger P, Compton SJ, Molimard M, et al. Mast cell tryptase as a mediator of hyperresponsiveness in human isolated bronchi. Clin Exp Allergy 1999; 29: 804-812.

31 Lazaar AL, Albelda SM, Pilewski JM, et al. T lymphocytes adhere to airway smooth muscle cells via integrins and CD44 and induce smooth muscle cell DNA synthesis. J Exp Med 1994; 180: 807-816.

32 Ramos-Barbon D, Presley JF, Hamid QA, et al. Antigen-specific $\mathrm{CD} 4+\mathrm{T}$ cells drive airway smooth muscle remodeling in experimental asthma. J Clin Invest 2005; 115: 1580-1589.

33 Fixman ED, Stewart A, Martin JG. Basic mechanisms of development of airway structural changes in asthma. Eur Respir J 2007; 29: 379-389.

34 Laitinen LA, Laitinen A, Altraja A, et al. Bronchial biopsy findings in intermittent or "early" asthma. J Allergy Clin Immunol 1996; 98: 3-6.

35 Pohunek P, Warner JO, Turzikova J, et al. Markers of eosinophilic inflammation and tissue re-modelling in children before clinically diagnosed bronchial asthma. Pediatr Allergy Immunol 2005; 16: 43-51.

36 Cokugras H, Akcakaya N, Seckin, et al. Ultrastructural examination of bronchial biopsy specimens from children with moderate asthma. Thorax 2001; 56: 25-29.

37 Bai TR, Cooper J, Koelmeyer T, et al. The effect of age and duration of disease on airway structure in fatal asthma. Am J Respir Crit Care Med 2000; 162: 663-669.

38 Thomson RJ, Schellenberg RR. Increased amount of airway smooth muscle does not account for excessive bronchoconstriction in asthma. Can Respir J 1998; 5: 61-62.

39 Araujo BB, Dolhnikoff M, Silva LF, et al. Extracellular matrix components and regulators in the airway smooth muscle in asthma. Eur Respir J 2008; 32: 61-69.

40 Johnson PR, Black JL, Carlin S, et al. The production of extracellular matrix proteins by human passively sensitized airway smooth-muscle cells in culture: the effect of beclomethasone. Am J Respir Crit Care Med 2000; 162: 2145-2151.

41 Johnson PR, Burgess JK, Underwood PA, et al. Extracellular matrix proteins modulate asthmatic airway smooth muscle cell proliferation via an autocrine mechanism. J Allergy Clin Immunol 2004; 113: 690-696.

42 Klagas I, Goulet S, Karakiulakis G, et al. Decreased hyaluronan in airway smooth muscle cells from patients with asthma and COPD. Eur Respir J 2009; 34: 616-628.

43 Roberts CR. Is asthma a fibrotic disease? Chest 1995; 107: 111-117.

44 Roche WR, Beasley R, Williams JH, et al. Subepithelial fibrosis in the bronchi of asthmatics. Lancet 1989; 1: 520-524.

45 Dolhnikoff M, da Silva LF, de Araujo BB, et al. The outer wall of small airways is a major site of remodeling in fatal asthma. J Allergy Clin Immunol 2009; 123: 1090-1097.

46 Wilson $\mathrm{JW}, \mathrm{Li} X$. The measurement of reticular basement membrane and submucosal collagen in the asthmatic airway. Clin Exp Allergy 1997; 27: 363-371.

47 Altraja A, Laitinen A, Virtanen I, et al. Expression of laminins in the airways in various types of asthmatic patients: a morphometric study. Am J Respir Cell Mol Biol 1996; 15: 482-488.

48 Ohno I, Ohtani H, Nitta Y, et al. Eosinophils as a source of matrix metalloproteinase-9 in asthmatic airway inflammation. Am Respir Cell Mol Biol 1997; 16: 212-219.

49 Chandler S, Cossins J, Lury J, et al. Macrophage metalloelastase degrades matrix and myelin proteins and processes a tumour necrosis factor- $\alpha$ fusion protein. Biochem Biophys Res Commun 1996; 228: 421-429.

50 Gronski TJ Jr, Martin RL, Kobayashi DK, et al. Hydrolysis of a broad spectrum of extracellular matrix proteins by human macrophage elastase. J Biol Chem 1997; 272: 12189-12194. 
51 Elshaw SR, Henderson N, Knox AJ, et al. Matrix metalloproteinase expression and activity in human airway smooth muscle cells. Br J Pharmacol 2004; 142: 1318-1324.

52 Xie S, Issa R, Sukkar MB, et al. Induction and regulation of matrix metalloproteinase-12 in human airway smooth muscle cells. Respir Res 2005; 6: 148.

53 Lemjabbar H, Gosset P, Lamblin C, et al. Contribution of $92 \mathrm{kDa}$ gelatinase/type IV collagenase in bronchial inflammation during status asthmaticus. Am J Respir Crit Care Med 1999; 159: 1298-1307.

54 Dahlen B, Shute J, Howarth P. Immunohistochemical localisation of the matrix metalloproteinases MMP-3 and MMP-9 within the airways in asthma. Thorax 1999; 54: 590-596.

55 Mautino G, Henriquet C, Jaffuel D, et al. Tissue inhibitor of metalloproteinase-1 levels in bronchoalveolar lavage fluid from asthmatic subjects. Am J Respir Crit Care Med 1999; 160: 324-330.

56 Lee CG, Homer RJ, Zhu Z, et al. Interleukin-13 induces tissue fibrosis by selectively stimulating and activating transforming growth factor $\beta 1$. J Exp Med 2001; 194: 809-821.

57 Redington AE, Madden J, Frew AJ, et al. Transforming growth factor-beta 1 in asthma. Measurement in bronchoalveolar lavage fluid. Am J Respir Crit Care Med 1997; 156: 642-647.

58 Vignola AM, Chanez P, Chiappara G, et al. Transforming growth factor- $\beta$ expression in mucosal biopsies in asthma and chronic bronchitis. Am J Respir Crit Care Med 1997; 156: 591-599.

59 Johnson PR, Burgess JK, Ge Q, et al. Connective tissue growth factor induces extracellular matrix in asthmatic airway smooth muscle. Am J Respir Crit Care Med 2006; 173: 32-41.

60 Burgess JK, Johnson PR, Ge Q, et al. Expression of connective tissue growth factor in asthmatic airway smooth muscle cells. Am J Respir Crit Care Med 2003; 167: 71-77.

61 Raghow R. The role of extracellular matrix in postinflammatory wound healing and fibrosis. FASEB J 1994; 8: 823-831.

62 Dekkers BG, Schaafsma D, Nelemans SA, et al. Extracellular matrix proteins differentially regulate airway smooth muscle phenotype and function. Am J Physiol Lung Cell Mol Physiol 2007; 292: 1405-1413.

63 Tran T, McNeill KD, Gerthoffer WT, et al. Endogenous laminin is required for human airway smooth muscle cell maturation. Respir Res 2006; 7: 117.

64 Hirst SJ, Twort CH, Lee TH. Differential Effects of extracellular matrix proteins on human airway smooth muscle cell proliferation and phenotype. Am J Respir Cell Mol Biol 2000; 23: 335-344.

65 Benayoun L, Druilhe A, Dombret MC, et al. Airway structural alterations selectively associated with severe asthma. Am J Respir Crit Care Med 2003; 167: 1360-1368.

66 Woodruff PG, Dolganov GM, Ferrando RE, et al. Hyperplasia of smooth muscle in mild to moderate asthma without changes in cell size or gene expression. Am J Respir Crit Care Med 2004; 169: 1001-1006.

67 Ebina M, Takahashi T, Chiba T, et al. Cellular hypertrophy and hyperplasia of airway smooth muscles underlying bronchial asthma. A 3-D morphometric study. Am Rev Respir Dis 1993; 148: 720-726.

68 Zhou L, Li J, Goldsmith AM, et al. Human bronchial smooth muscle cell lines show a hypertrophic phenotype typical of severe asthma. Am J Respir Crit Care Med 2004; 169: 703-711.

69 Halayko AJ, Kartha S, Stelmack GL, et al. Phophatidylinositol-3 kinase/mammalian target of rapamycin/p70S6K regulates contractile protein accumulation in airway myocyte differentiation. Am J Respir Cell Mol Biol 2004; 31: 266-275.

70 Goldsmith AM, Bentley JK, Zhou L, et al. Transforming growth factor- $\beta$ induces airway smooth muscle hypertrophy. Am J Respir Cell Mol Biol 2006; 34: 247-254.

71 McWhinnie R, Pechkovsky DV, Zhou D, et al. Endothelin-1 induces hypertrophy and inhibits apoptosis in human airway smooth muscle cells. Am J Physiol Lung Cell Mol Physiol 2007; 292: 278-286.
72 Zhou D, Zheng X, Wang L, et al. Expression and effects of cardiotrophin-1 (CT-1) in human airway smooth muscle cells. $\mathrm{Br}$ J Pharmacol 2003; 140: 1237-1244.

73 Bentley JK, Hershenson MB. Airway smooth muscle growth in asthma: proliferation, hypertrophy, and migration. Proc Am Thorac Soc 2008; 5: 89-96.

74 Zhou L, Goldsmith AM, Bentley JK, et al. 4E-binding protein phosphorylation and eukaryotic initiation factor-4E release are required for airway smooth muscle hypertrophy. Am J Respir Cell Mol Biol 2005; 33: 195-202.

75 Deng H, Hershenson MB, Lei J, et al. p70 ribosomal S6 kinase is required for airway smooth muscle cell size enlargement but not increased contactile protein expression. Am J Respir Cell Mol Biol 2010; 42: 744-752.

76 Inoki K, Ouyang H, Zhu T, et al. TSC2 integrates Wnt and energy signals via a coordinated phosphorylation by AMPK and GSK3 to regulate cell growth. Cell 2006; 126: 955-968.

77 Welsh GI, Miller CM, Loughlin AJ, et al. Regulation of eukaryotic initiation factor eIF2B: glycogen synthase kinase-3 phosphorylates a conserved serine which undergoes dephosphorylation in response to insulin. FEBS Lett 1998; 421: 125-130.

78 Hardt SE, Tomita H, Katus HA, et al. Phosphorylation of eukaryotic translation initiation factor $2 \mathrm{~B} \varepsilon$ by glycogen synthase kinase- $3 \beta$ regulates beta-adrenergic cardiac myocyte hypertrophy. Circ Res 2004; 94: 926-935.

79 Deng H, Dokshin GA, Lei J, et al. Inhibition of glycogen synthase kinase-3 $\beta$ is sufficient for airway smooth muscle hypertrophy. J Biol Chem 2008; 283: 10198-10207.

80 Bentley JK, Deng H, Linn MJ, et al. Airway smooth muscle hyperplasia and hypertrophy correlate with glycogen synthase kinase-3 $\beta$ phosphorylation in a mouse model of asthma. Am J Physiol Lung Cell Mol Physiol 2009; 296: 176-184.

81 Trian T, Benard G, Begueret H, et al. Bronchial smooth muscle remodeling involves calcium-dependent enhanced mitochondrial biogenesis in asthma. J Exp Med 2007; 204: 3173-3181.

82 Hossain S. Quantitative measurement of bronchial muscle in men with asthma. Am Rev Respir Dis 1973; 107: 99-109.

83 Hirst SJ. Airway smooth muscle cell culture: application to studies of airway wall remodelling and phenotype plasticity in asthma. Eur Respir J 1996; 9: 808-820.

84 Hirst SJ, Barnes PJ, Twort CH. PDGF isoform-induced proliferation and receptor expression in human cultured airway smooth muscle cells. Am J Physiol 1996; 270: 415-428.

85 Hawker KM, Johnson PRA, Hughes JM, et al. Interleukin-4 inhibits mitogen-induced proliferation of human airway smooth muscle cells in culture. Am J Physiol 1998; 275: 469-477.

86 Panettieri RA Jr, Goldie RG, Rigby PJ, et al. Endothelin-1-induced potentiation of human airway smooth muscle proliferation: an ETA receptor-mediated phenomenon. Br J Pharmacol 1996; 118: 191-197.

87 Stewart AG, Tomlinson PR, Fernandes DJ, et al. Tumor necrosis factor $\alpha$ modulates mitogenic responses of human cultured airway smooth muscle. Am J Respir Cell Mol Biol 1995; 12: 110-119.

88 Cohen MD, Ciocca V, Panettieri RA Jr. TGF- $\beta 1$ modulates human airway smooth-muscle cell proliferation induced by mitogens. Am J Respir Cell Mol Biol 1997; 16: 85-90.

89 Xie S, Sukkar MB, Issa R, et al. Mechanisms of induction of airway smooth muscle hyperplasia by transforming growth factor-beta. Am J Physiol Lung Cell Mol Physiol 2007; 293: 245-253.

90 Maruno K, Absood A, Said SI. VIP inhibits basal and histaminestimulated proliferation of human airway smooth muscle cells. Am J Physiol 1995; 268: 1047-1051.

91 Tomlinson PR, Wilson JW, Stewart AG. Inhibition by salbutamol of the proliferation of human airway smooth muscle cells grown in culture. Br J Pharmacol 1994; 111: 641-647.

92 Capra V, Habib A, Accomazzo MR, et al. Thromboxane prostanoid receptor in human airway smooth muscle cells: a relevant role in proliferation. Eur J Pharmacol 2003; 474: 149-159. 
93 Ravasi S, Citro S, Viviani B, et al. CysLT1 receptor-induced human airway smooth muscle cells proliferation requires ROS generation, EGF receptor transactivation and ERK1/2 phosphorylation. Respir Res 2006; 7: 42.

94 Ammit AJ, Hastie AT, Edsall LC, et al. Sphingosine 1-phosphate modulates human airway smooth muscle cell functions that promote inflammation and airway remodeling in asthma. FASEB J 2001; 15: 1212-1214.

95 Berger P, Perng DW, Thabrew H, et al. Tryptase and agonists of PAR-2 induce the proliferation of human airway smooth muscle cells. J Appl Physiol 2001; 91: 1372-1379.

96 Panettieri RA Jr, Hall IP, Maki CS, et al. alpha-Thrombin increases cytosolic calcium and induces human airway smooth muscle cell proliferation. Am J Respir Cell Mol Biol 1995; 13: 205-216.

97 Huang $\mathrm{CD}$, Chen $\mathrm{HH}$, Wang $\mathrm{CH}$, et al. Human neutrophilderived elastase induces airway smooth muscle cell proliferation. Life Sci 2004; 74: 2479-2492.

98 Pandya HC, Snetkov VA, Twort $\mathrm{CH}$, et al. Oxygen regulates mitogen-stimulated proliferation of fetal human airway smooth muscle cells. Am J Physiol Lung Cell Mol Physiol 2002; 283: 1220-1230.

99 Smith PG, Janiga KE, Bruce MC. Strain increases airway smooth muscle cell proliferation. Am J Respir Cell Mol Biol 1994; 10: 85-90.

100 Tliba O, Panettieri RA Jr. Noncontractile functions of airway smooth muscle cells in asthma. Annu Rev Physiol 2009; 71 : 509-535.

101 Engelman JA, Luo J, Cantley LC. The evolution of phosphatidylinositol 3-kinases as regulators of growth and metabolism. Nat Rev Genet 2006; 7: 606-619.

102 Abo A, Boyhan A, West I, et al. Reconstitution of neutrophil NADPH oxidase activity in the cell-free system by four components: p67-phox, p47-phox, p21rac1, and cytochrome b245. J Biol Chem 1992; 267: 16767-16770.

103 Brar SS, Kennedy TP, Sturrock AB, et al. NADPH oxidase promotes NF- $\kappa \mathrm{B}$ activation and proliferation in human airway smooth muscle. Am J Physiol Lung Cell Mol Physiol 2002; 282: 782-795.

104 Ravenhall C, Guida E, Harris T, et al. The importance of ERK activity in the regulation of cyclin D1 levels and DNA synthesis in human cultured airway smooth muscle. Br J Pharmacol 2000; 131: 17-28.

105 Page K, Li J, Hodge JA, et al. Characterization of a Rac1 signaling pathway to cyclin $\mathrm{D}(1)$ expression in airway smooth muscle cells. J Biol Chem 1999; 274: 22065-22071.

106 Abe MK, Chao TS, Solway J, et al. Hydrogen peroxide stimulates mitogen-activated protein kinase in bovine tracheal myocytes: implications for human airway disease. Am J Respir Cell Mol Biol 1994; 11: 577-585.

107 Abe MK, Kartha S, Karpova AY, et al. Hydrogen peroxide activates extracellular signal-regulated kinase via protein kinase C, Raf-1, and MEK1. Am J Respir Cell Mol Biol 1998; 18: 562-569.

108 Krymskaya VP, Orsini MJ, Eszterhas AJ, et al. Mechanisms of proliferation synergy by receptor tyrosine kinase and $G$ proteincoupled receptor activation in human airway smooth muscle. Am J Respir Cell Mol Biol 2000; 23: 546-554.

109 Walker TR, Moore SM, Lawson MF, et al. Platelet-derived growth factor-BB and thrombin activate phosphoinositide 3kinase and protein kinase B: role in mediating airway smooth muscle proliferation. Mol Pharmacol 1998; 54: 1007-1015.

110 Brown JK, Jones CA, Rooney LA, et al. Tryptase's potent mitogenic effects in human airway smooth muscle cells are via nonproteolytic actions. Am J Physiol Lung Cell Mol Physiol 2002; 282: 197-206.

111 Trian T, Girodet PO, Ousova O, et al. RNA interference decreases PAR-2 expression and function in human airway smooth muscle cells. Am J Respir Cell Mol Biol 2006; 34: 49-55.
112 Berger P, Tunon-de-Lara JM, Savineau JP, et al. Tryptase-induced PAR-2-mediated $\mathrm{Ca}^{2+}$ signaling in human airway smooth muscle cells. J Appl Physiol 2001; 91: 995-1003.

113 Hasaneen NA, Zucker S, Cao J, et al. Cyclic mechanical straininduced proliferation and migration of human airway smooth muscle cells: role of EMMPRIN and MMPs. FASEB J 2005; 19: 1507-1509.

114 Naureckas ET, Ndukwu IM, Halayko AJ, et al. Bronchoalveolar lavage fluid from asthmatic subjects is mitogenic for human airway smooth muscle. Am J Respir Crit Care Med 1999; 160: 2062 2066.

115 Johnson PR, Roth M, Tamm M, et al. Airway smooth muscle cell proliferation is increased in asthma. Am J Respir Crit Care Med 2001; 164: 474-477.

116 Burgess JK, Lee JH, Ge Q, et al. Dual ERK and phosphatidylinositol 3-kinase pathways control airway smooth muscle proliferation: differences in asthma. J Cell Physiol 2008; 216: 673-679.

117 Borger $\mathrm{P}$, Miglino N, Baraket M, et al. Impaired translation of CCAAT/enhancer binding protein $\alpha$ mRNA in bronchial smooth muscle cells of asthmatic patients. J Allergy Clin Immunol 2009; 123: 639-645.

118 Mahn K, Hirst SJ, Ying S, et al. Diminished sarco/endoplasmic reticulum $\mathrm{Ca}^{2+}$ ATPase (SERCA) expression contributes to airway remodelling in bronchial asthma. Proc Natl Acad Sci USA 2009; 106: 10775-10780.

119 Stewart AG, Fernandes D, Tomlinson PR. The effect of glucocorticoids on proliferation of human cultured airway smooth muscle. Br J Pharmacol 1995; 116: 3219-3226.

120 Fernandes D, Guida E, Koutsoubos V, et al. Glucocorticoids inhibit proliferation, cyclin D1 expression, and retinoblastoma protein phosphorylation, but not activity of the extracellularregulated kinases in human cultured airway smooth muscle. Am J Respir Cell Mol Biol 1999; 21: 77-88.

121 Adcock IM, Gilbey T, Gelder CM, et al. Glucocorticoid receptor localization in normal and asthmatic lung. Am J Respir Crit Care Med 1996; 154: 771-782.

122 Lekstrom-Himes J, Xanthopoulos KG. Biological role of the CCAAT/enhancer-binding protein family of transcription factors. J Biol Chem 1998; 273: 28545-28548.

123 Rudiger JJ, Roth M, Bihl MP, et al. Interaction of C/EBPalpha and the glucocorticoid receptor in vivo and in nontransformed human cells. FASEB J 2002; 16: 177-184.

124 Borger P, Tamm M, Black JL, et al. Asthma: is it due to an abnormal airway smooth muscle cell? Am J Respir Crit Care Med 2006; 174: 367-372

125 Lambert RK, Wiggs BR, Kuwano K, et al. Functional significance of increased airway smooth muscle in asthma and COPD. J Appl Physiol 1993; 74: 2771-2781.

126 Hamann KJ, Vieira JE, Halayko AJ, et al. Fas cross-linking induces apoptosis in human airway smooth muscle cells. Am J Physiol Lung Cell Mol Physiol 2000; 278: 618-624

127 Oltmanns U, Sukkar MB, Xie S, et al. Induction of human airway smooth muscle apoptosis by neutrophils and neutrophil elastase. Am J Respir Cell Mol Biol 2005; 32: 334-341.

128 D'Antoni ML, Torregiani C, Ferraro P, et al. Effects of decorin and biglycan on human airway smooth muscle cell proliferation and apoptosis. Am J Physiol Lung Cell Mol Physiol 2008; 294: 764-771.

129 de Medeiros Matsushita M, da Silva LF, dos Santos MA, et al. Airway proteoglycans are differentially altered in fatal asthma. J Pathol 2005; 207: 102-110.

130 Kaur D, Hollins F, Saunders R, et al. Airway smooth muscle proliferation and survival is not modulated by mast cells. Clin Exp Allergy 2010; 40: 279-288.

131 Robertson NM, Zangrilli JG, Steplewski A, et al. Differential expression of TRAIL and TRAIL receptors in allergic 
asthmatics following segmental antigen challenge: evidence for a role of TRAIL in eosinophil survival. J Immunol 2002; 169: 5986-5996.

132 Gerthoffer WT. Migration of airway smooth muscle cells. Proc Am Thorac Soc 2008; 5: 97-105.

133 Madison JM. Migration of airway smooth muscle cells. Am J Respir Cell Mol Biol 2003; 29: 8-11.

134 Hirst SJ, Martin JG, Bonacci JV, et al. Proliferative aspects of airway smooth muscle. J Allergy Clin Immunol 2004; 114: 2-17.

135 Mukhina S, Stepanova V, Traktouev D, et al. The chemotactic action of urokinase on smooth muscle cells is dependent on its kringle domain. Characterization of interactions and contribution to chemotaxis. J Biol Chem 2000; 275: 16450-16458.

136 Parameswaran K, Radford K, Zuo J, et al. Extracellular matrix regulates human airway smooth muscle cell migration. Eur Respir J 2004; 24: 545-551.

137 Joubert $\mathrm{P}$, Lajoie-Kadoch S, Labonte I, et al. CCR3 expression and function in asthmatic airway smooth muscle cells. J Immunol 2005; 175: 2702-2708.

138 Govindaraju V, Michoud MC, Al-Chalabi M, et al. Interleukin-8: novel roles in human airway smooth muscle cell contraction and migration. Am J Physiol Cell Physiol 2006; 291: 957-965.

139 Kaur D, Saunders R, Berger P, et al. Airway smooth muscle and mast cell-derived CC chemokine ligand 19 mediate airway smooth muscle migration in asthma. Am J Respir Crit Care Med 2006; 174: 1179-1188.

140 Takeda N, Sumi Y, Prefontaine D, et al. Epithelium-derived chemokines induce airway smooth muscle cell migration. Clin Exp Allergy 2009; 39: 1018-1026.

141 Ito I, Fixman ED, Asai K, et al. Platelet-derived growth factor and transforming growth factor- $\beta$ modulate the expression of matrix metalloproteinases and migratory function of human airway smooth muscle cells. Clin Exp Allergy 2009; 39: 1370-1380.

142 Gizycki MJ, Adelroth E, Rogers AV, et al. Myofibroblast involvement in the allergen-induced late response in mild atopic asthma. Am J Respir Cell Mol Biol 1997; 16: 664-673.

143 Powell DW, Mifflin RC, Valentich JD, et al. Myofibroblasts. I. Paracrine cells important in health and disease. Am J Physiol 1999; 277: 1-9.

144 Schmidt M, Sun G, Stacey MA, et al. Identification of circulating fibrocytes as precursors of bronchial myofibroblasts in asthma. J Immunol 2003; 171: 380-389.

145 Willis BC, duBois RM, Borok Z. Epithelial origin of myofibroblasts during fibrosis in the lung. Proc Am Thorac Soc 2006; 3: 377-382.

146 Ronnov-Jessen L, Petersen OW, Koteliansky VE, et al. The origin of the myofibroblasts in breast cancer. Recapitulation of tumor environment in culture unravels diversity and implicates converted fibroblasts and recruited smooth muscle cells. J Clin Invest 1995; 95: 859-873.

147 Wicks J, Haitchi HM, Holgate ST, et al. Enhanced upregulation of smooth muscle related transcripts by TGF $\beta 2$ in asthmatic (myo) fibroblasts. Thorax 2006; 61: 313-319.

148 Saunders R, Siddiqui S, Kaur D, et al. Fibrocyte localization to the airway smooth muscle is a feature of asthma. J Allergy Clin Immunol 2009; 123: 376-384.
149 Bucala R, Spiegel LA, Chesney J, et al. Circulating fibrocytes define a new leukocyte subpopulation that mediates tissue repair. Mol Med 1994; 1: 71-81.

150 Wang $\mathrm{CH}$, Huang $\mathrm{CD}$, Lin $\mathrm{HC}$, et al. Increased circulating fibrocytes in asthma with chronic airflow obstruction. Am J Respir Crit Care Med 2008; 178: 583-591.

151 Strieter RM, Gomperts BN, Keane MP. The role of CXC chemokines in pulmonary fibrosis. J Clin Invest 2007; 117: 549-556.

152 Nihlberg K, Larsen K, Hultgardh-Nilsson A, et al. Tissue fibrocytes in patients with mild asthma: a possible link to thickness of reticular basement membrane? Respir Res 2006; 7: 50.

153 Kalluri R, Neilson EG. Epithelial-mesenchymal transition and its implications for fibrosis. J Clin Invest 2003; 112: 1776-1784.

154 Iwano M, Plieth D, Danoff TM, et al. Evidence that fibroblasts derive from epithelium during tissue fibrosis. J Clin Invest 2002; 110: 341-350.

155 Hackett TL, Warner SM, Stefanowicz D, et al. Induction of epithelial-mesenchymal transition in primary airway epithelial cells from patients with asthma by transforming growth factorB1. Am J Respir Crit Care Med 2009; 180: 122-133.

156 Doerner AM, Zuraw BL. TGF- $\beta 1$ induced epithelial to mesenchymal transition (EMT) in human bronchial epithelial cells is enhanced by IL-1 $\beta$ but not abrogated by corticosteroids. Respir Res 2009; 10: 100.

157 Malavia NK, Raub CB, Mahon SB, et al. Airway epithelium stimulates smooth muscle proliferation. Am J Respir Cell Mol Biol 2009; 41: 297-304.

158 Chanez P. Severe asthma is an epithelial disease. Eur Respir J 2005; 25: 945-946.

159 Holgate ST, Roberts G, Arshad HS, et al. The role of the airway epithelium and its interaction with environmental factors in asthma pathogenesis. Proc Am Thorac Soc 2009; 6: 655-659.

160 Trian T, Ge Q, Moir LM, et al. Rhinovirus-induced exacerbations of asthma: how is the $\beta 2$-adrenoceptor implicated? Am J Respir Cell Mol Biol 2010; 43: 227-233.

161 Roberts KE, Preston IR. Safety and tolerability of bosentan in the management of pulmonary arterial hypertension. Drug Des Devel Ther 2009; 3: 111-118.

162 Leung SY, Niimi A, Noble A, et al. Effect of transforming growth factor-beta receptor I kinase inhibitor 2,4-disubstituted pteridine (SD-208) in chronic allergic airway inflammation and remodeling. J Pharmacol Exp Ther 2006; 319: 586-594.

163 Ghavami S, Mutawe M, Hauff K, et al. Statin-triggered cell death in primary human lung mesenchymal cells involves p53-PUMA and release of Smac and Omi but not cytochrome c. Biochimica et Biophysica Acta 2010; 1803: 452-467.

164 Camoretti-Mercado B Targeting the airway smooth muscle for asthma treatment, Transl Res 2009; 154: 165-174.

165 Lederlin M, Ozier A, Montaudon M, et al. Airway remodeling in a mouse asthma model assessed by in-vivo respiratory-gated micro-computed tomography. Eur Radiol 2009; 20: 128-137.

166 Montaudon M, Berger P, Lederlin M, et al. Bronchial morphometry in smokers: comparison with healthy subjects by using 3D CT. Eur Radiol 2009; 19: 1328-1334.

167 Montaudon M, Berger P, Blachere $\mathrm{H}$, et al. Thin-section CT of the lung: influence of 0.5 -s gantry rotation and ECG triggering on image quality. Eur Radiol 2001; 11: 1681-1687. 